\title{
Mechanism of action of oxidized polyamines on the metabolism of human spermatozoa
}

\author{
P. Pulkkinen, R. Sinervirta and J. Jänne \\ Department of Biochemistry, University of Helsinki, SF-00170 Helsinki 17, Finland
}

\begin{abstract}
Summary. Oxidized spermine, an iminoaldehyde ( $N, N^{\prime}$-bis(3-propionaldehyde) 1,4-diaminobutane), is a non-competitive inhibitor of fructolysis by human spermatozoa. The inhibition constant is about $0.3 \mathrm{~mm}$. In experiments with [U- ${ }^{14} \mathrm{C}$ ]fructose the iminoaldehyde caused a more pronounced depression of the formation of $\mathrm{CO}_{2}$ than of lactate. The iminoaldehyde was without influence on the conversion of fructose to lactate by cell-free extracts of spermatozoa, but it markedly decreased the uptake of fructose and lactate by spermatozoa. These findings strongly suggest that inhibition of the fructose metabolism of intact spermatozoa was due to interaction of the iminoaldehyde with sperm membranes and not to inhibition of any enzyme of the glycolytic pathway. Several aliphatic and aromatic aldehydes were also tested for their ability to inhibit sugar utilization of human spermatozoa: only $n$-hexanal exerted an inhibitory effect, the extent of which approached that of oxidized spermine.
\end{abstract}

\section{Introduction}

Tabor \& Rosenthal (1956) found that incubation of motile spermatozoa of several mammalian species (including man, bull and rat) in the presence of an amine oxidase from ruminant blood together with spermine or spermidine resulted in a swift loss of motility of the sperm cells. The spermicidal effect appeared to be attributable to oxidation products of the polyamines (Tabor \& Rosenthal, 1956). Because oxidized polyamines are extremely toxic to mammalian spermatozoa whether formed in situ in semen in the amine oxidase catalysed reaction (Tabor \& Rosenthal, 1956) or added as synthetic iminoaldehydes (Pulkkinen, Sinervirta \& Jänne, 1975b), we have explored in more detail the mechanism of action of these compounds on the metabolism of human spermatozoa.

\section{Materials and Methods}

Semen was obtained from a local analytical laboratory. Based on motility and morphology, apparently normal, pooled semen samples (obtained from 3 to 6 men) were first diluted $(1: 1)$ with a Ringer solution containing $123 \mathrm{~mm}-\mathrm{NaCl}, 5 \mathrm{~mm}-\mathrm{KCl}, 1 \mathrm{~mm}-\mathrm{MgSO}_{4}, 500 \mathrm{i}$.u. benzylpenicillin $/ \mathrm{ml}$ and $0.2 \mathrm{mg}$ streptomycin sulphate/ml and buffered with $37 \mathrm{~mm}$-Tris-HCl, pH 8.0 (Murdoch \& White, 1968; Eliasson, 1971). The spermatozoa were separated from seminal plasma by low-speed centrifugation $(30 \mathrm{~g})$ at room temperature, washed twice with the Ringer solution and suspended in the same solution at a concentration of $5-10 \times 10^{7}$ cells $/ \mathrm{ml}$. When cell-free extracts were required the washed cells were disintegrated with a Branson Sonifier using an ice-ethanol bath for cooling (six times for $10 \mathrm{sec}$ at maximum power). The suspension was centrifuged at $105,000 \mathrm{~g}$ for $15 \mathrm{~min}$ and the supernatant was used as the source of glycolytic enzymes.

Chemicals. $\left[\mathrm{U}-{ }^{14} \mathrm{C}\right]$ Fructose (sp. act. $100 \mathrm{mCi} / \mathrm{mmol}$ ) and $\left[2-{ }^{14} \mathrm{C}\right]$ lactate (sp. act. $29 \mathrm{mCi} / \mathrm{mmol}$ ) were purchased from the Radiochemical Centre (Amersham, England). $\left[1,4-{ }^{14} \mathrm{C}\right] \mathrm{Spermine}$ (sp. act. $18.75 \mathrm{mCi} / \mathrm{mmol}$ ) was obtained from the New England Nuclear Corporation (Boston, U.S.A.). Except for oxidized spermine (see below) all other chemicals were obtained commercially.

Amine oxidase was partly purified from bovine blood through the DEAE-cellulose step of the method of Yamada \& Yasunotu (1962). Oxidized spermine ( $N, N^{\prime}$-bis(3-propionaldehyde)-1,4diaminobutane) was prepared with the aid of partly purified amine oxidase. It was isolated from the incubation mixture and purified as described by Pulkkinen, Kanerva, Elfving \& Jänne (1975a). 


\section{Measurement of fructolysis}

Washed spermatozoa $\left(10^{8} / \mathrm{ml}\right)$ were preincubated at $37^{\circ} \mathrm{C}(\mathrm{pH} 8.0)$ with various additions (see 'Results') for $20 \mathrm{~min}$ unless otherwise indicated. Then $0.5 \mu \mathrm{Ci}$ [U $-{ }^{14} \mathrm{C}$ ]fructose (final concentration $0.025 \mathrm{~mm}$ unless otherwise indicated) was added and the incubation continued for another $60 \mathrm{~min}$. The final volume in each incubation vessel was $0.4 \mathrm{ml}$. Metabolism was halted by addition of $0.5 \mathrm{ml}$ $25 \%(\mathrm{w} / \mathrm{v})$ trichloroacetic acid. The evolved carbon dioxide was collected in $0.1 \mathrm{ml}$ Soluene (Packard Instrument Company) and counted for radioactivity. For lactate determination $0.2 \mathrm{ml}$ of the proteinfree supernatant solution from the incubation mixture was assayed by the method of Hoskins \& Patterson(1968).

In experiments with the cell-free extract, the incubation mixture contained, in addition to sperm extract and radioactive fructose, $2 \mathrm{~mm}$-ATP, $2 \mathrm{~mm}-\mathrm{NAD}^{+}, 20 \mathrm{~mm}$-potassium phosphate, $5 \mathrm{mM}-\mathrm{MgSO}_{4}, 5 \mathrm{mM}-\mathrm{Tris}-\mathrm{HCl}(\mathrm{pH} 8.0)$ and $10 \mu \mathrm{g}$ hexokinase (crystallized from yeast; Boehringer, Mannheim). The incubation conditions and the measurement of lactate were as described above.

\section{Assay of sperm uptake of oxidized spermine, fructose and lactate}

The sperm cell suspensions were incubated for $30 \mathrm{~min}$ at $37^{\circ} \mathrm{C}$ with various additions (see 'Results'). The reactions were halted by diluting the suspensions with $1 \mathrm{ml}$ Ringer solution and the sperm cells were separated immediately by low-speed centrifugation $(30 \mathrm{~g})$ for $3 \mathrm{~min}$ at room temperature. The cells were washed twice with Ringer solution, suspended with a small volume of Ringer in Instagel (Packard Instrument Company) and counted for radioactivity.

\section{Results}

\section{Effect of amine oxidase and oxidized spermine on fructolysis}

In agreement with the earlier report of Tabor \& Rosenthal (1956), partly purified amine oxidase from bovine blood rapidly immobilized human spermatozoa in whole semen or in Ringer solution plus exogenous spermine. Table 1 illustrates that the fructolysis by washed sperm cells was depressed during incubation with partly purified amine oxidase. A remarkable inhibition of fructolysis was achieved even in the absence of exogenous amine substrates. This inhibition was probably due to the oxidation of seminal spermine that remained attached to the spermatozoa (see Pulkkinen et al. 1975b). The inclusion of catalase in the incubation mixture (Table 1) reduced the inhibitory action of spermine. Although slightly higher concentrations of oxidized spermine (in comparison with those in the presence of amine oxidase) were required to inhibit fructolysis, the iminoaldehydes arising from the oxidation of polyamines were primarily, if not necessarily exclusively, responsible for the deleterious influence exerted by amine oxidase plus polyamine on human spermatozoa.

Table 1. Effect of amine oxidase + spermine, amine oxidase + spermine + catalase and oxidized spermine on the formation of $\left[{ }^{14} \mathrm{C}\right]$ lactate from uniformly labelled fructose by human spermatozoa

\begin{tabular}{cccc}
\hline \multirow{2}{*}{$\begin{array}{c}\text { Conc. of spermine or } \\
\text { oxidized spermine (mM) }\end{array}$} & \multicolumn{3}{c}{$\left[^{14} \mathrm{C}\right]$ lactate (relative formation) in the presence of: } \\
\cline { 2 - 4 } & Amine oxidase* & Amine oxidase + catalase $\dagger$ & Oxidized spermine \\
\hline 0 & 0.29 & 0.64 & 1.00 \\
0.05 & 0.06 & 0.49 & 0.97 \\
0.10 & 0.01 & 0.31 & 0.90 \\
0.50 & 0.00 & 0.03 & 0.23 \\
1.00 & 0.00 & 0.07 & 0.19 \\
\hline & $*$ & \\
& &
\end{tabular}




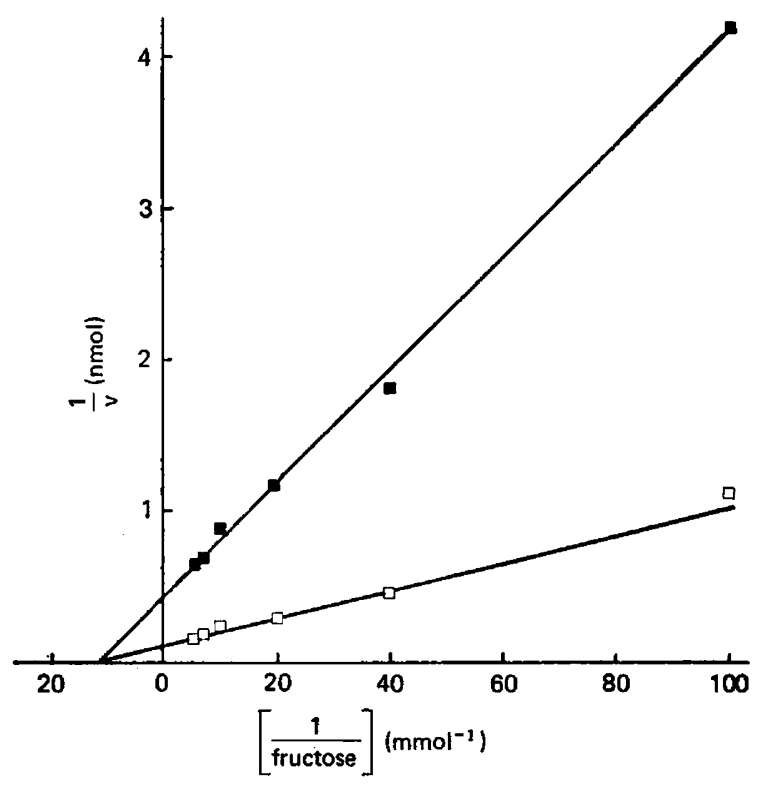

Text-fig. 1. Lineweaver-Burk plot of the effect of oxidized spermine on sperm fructolysis at different concentrations of fructose. Spermatozoa $\left(10^{8} \mathrm{cells} / \mathrm{ml}\right)$ were incubated in the absence or presence of $1 \mathrm{mM}$ oxidized spermine for $20 \mathrm{~min}$ at $37^{\circ} \mathrm{C}$. Labelled fructose was then added and the radioactive $\mathrm{CO}_{2}$ measured as described in the text. The double reciprocal lines were computed by the least squares method. Incubation with $(\square, 1 \mathrm{~mm})$ and without $(\square)$ oxidized spermine.

\section{Effect of oxidized spermine on sperm fructolysis at different concentrations of fructose}

Oxidized spermine (1 mM) gave rise to a noncompetitive type of inhibition (in respect of fructose) of sperm fructolysis (Text-fig. 1). An inhibition constant of about $0.3 \mathrm{~mm}$ was calculated for oxidized spermine. Table 2 shows the inhibition of production of ${ }^{14} \mathrm{CO}_{2}$ and $\left[{ }^{14} \mathrm{C}\right]$ lactate at different concentrations of fructose in the presence of oxidized spermine. The inhibition of the formation of labelled lactate was slightly less than that of the ${ }^{14} \mathrm{CO}_{2}$ formation. This difference was seen at every concentration of fructose. Table 3 shows that although oxidized spermine markedly inhibited sperm fructolysis even when added directly to the incubation mixture, the inhibition became more pronounced if the sperm cells were incubated at $37^{\circ} \mathrm{C}$ for short periods of time in the presence of the iminoaldehyde before the actual assay of fructose degradation.

Table 2. The effect of oxidized spermine (1 mM) on the production of $\mathrm{CO}_{2}$ and lactate by human spermatozoa from uniformly labelled fructose at different concentrations

\begin{tabular}{cccc}
\hline \multirow{2}{*}{$\begin{array}{c}\text { Conc. of fructose } \\
\text { (mM) }\end{array}$} & \multicolumn{3}{c}{ Percentage inhibition of the production of: } \\
\cline { 2 - 4 } & (a) ${ }^{14} \mathrm{CO}_{2}$ & (b) $\left[{ }^{14}\right.$ Cllactate & $\mathrm{a} / \mathrm{b}$ \\
\hline 0.01 & 73.5 & 68.2 & 1.08 \\
0.025 & 75.5 & 62.5 & 1.21 \\
0.05 & 73.8 & 59.6 & 1.24 \\
0.01 & 74.6 & 67.4 & 1.11 \\
0.15 & 74.5 & 66.1 & 1.13 \\
0.20 & 76.1 & 64.4 & 1.18 \\
\hline
\end{tabular}


Table 3. Effect of prior incubation on the inhibition of sperm fructolysis by oxidized spermine (1 mM)

\begin{tabular}{cccc}
\hline \multirow{2}{*}{$\begin{array}{c}\text { Time of prior } \\
\text { incubation } \\
(\mathrm{min})\end{array}$} & $\begin{array}{c}\text { Oxidized } \\
\text { spermine } \\
\text { present }\end{array}$ & \multicolumn{2}{c}{ Formation (pmol/108 cells) of: } \\
\cline { 3 - 4 } & - & ${ }^{14} \mathrm{CO}_{2}(\%)$ & {$\left[{ }^{14} \mathrm{C}\right]$ lactate $(\%)$} \\
\hline 0 & + & $5370(100)$ & $7720(100)$ \\
20 & - & $1720(32)$ & $3580(46)$ \\
& + & $5320(100)$ & $6940(100)$ \\
40 & - & $870(16)$ & $1850(27)$ \\
& + & $5580(100)$ & $7960(100)$ \\
\hline
\end{tabular}

\section{Uptake of oxidized spermine}

When motile sperm cells were incubated at $37^{\circ} \mathrm{C}$ in the presence of oxidized spermine the iminoaldehyde was rapidly taken up by the spermatozoa. There was a close association between the uptake of oxidized spermine and the depression in sperm fructolysis (Table 4). A 10-fold excess of spermine inhibited the uptake of the oxidized polyamine by about $15 \%$ and appeared to protect sperm fructolysis slightly against the depression evoked by the iminoaldehyde. Fructolysis seemed to be completely inhibited before any signs of a possible saturation of the uptake system for oxidized spermine were seen.

\section{Lack of effect of oxidized spermine on fructolysis in cell-free extracts}

When cell-free extracts of spermatozoa were used as a source of glycolytic enzymes, the production of lactate was negligible. However, when small amounts of hexokinase were added to the incubation mixture, the rate of lactate production increased dramatically, markedly exceeding that found in intact cells (see Table 5).

In the presence of $0.5 \mathrm{~mm}$ and $1.0 \mathrm{~mm}$ oxidized spermine the decrease in the production of lactate by cell free extracts was minimal, whereas addition of oxidized spermine in the intact cell suspension resulted in a $57 \%$ and $80 \%$ inhibition under the same conditions. These results suggest that oxidized polyamines do not interfere with sperm fructolysis.

\section{Effect of oxidized spermine on the uptake of fructose and lactate}

As indicated by the previous experiments, oxidized polyamines appeared to exert their inhibitory action on sperm fructolysis through a mechanism for which an intact cell structure is needed. Oxidized spermine inhibited the uptake processes involved in the transport of fructose and lactate, at least, into the sperm cell. In the presence of $0.5 \mathrm{~mm}$-iminoaldehyde, the uptake (calculated on the basis of total radioactivity plus the activity evolved as $\mathrm{CO}_{2}$ ) of fructose and lactate was inhibited by about $70 \%$ which is slightly less than the depression in fructose breakdown usually observed at this concentration of iminoaldehyde. The fact that lactate uptake was likewise decreased by the compound could possibly explain the more pronounced inhibition of $\mathrm{CO}_{2}$ formation than that of lactate production consistently seen in the presence of oxidized spermine. The iminoaldehyde is thus expected to inhibit the reabsorption of any lactate formed from fructose and being excreted extracellularly, thus decreasing the amount of lactate available for aerobic oxidation.

\section{Effect of various aliphatic and aromatic aldehydes on sperm fructolysis}

Table 6 shows that of the various aromatic and aliphatic aldehydes tested oxidized spermine was the most potent inhibitor of sperm fructolysis. At a concentration of $1 \mathrm{~mm}$, only $n$-hexanal $\left(\mathrm{CH}_{3}\right.$ $\left.\left(\mathrm{CH}_{2}\right)_{4} \mathrm{CHO}\right)$ approached the effect of oxidized spermine. Like oxidized spermine, this compound also inhibited the formation of labelled lactate less than that of $\mathrm{CO}_{2}$. Propionaldehyde and, $n$-butanol the shorter analogues of hexanol, exerted only minimal inhibition on sperm fructolysis. The inhibition of fructose breakdown by oxidized spermidine ( $\mathrm{N}$-(3-propionaldehyde)-1,4-diaminobutane) was comparable to that achieved with oxidized spermine (results not shown). 
Table 4. Incorporation of radioactivity into human spermatozoa from radioactive oxidized spermine and the inhibition of sperm fructolysis

\begin{tabular}{|c|c|c|c|}
\hline \multirow{2}{*}{$\begin{array}{l}\text { Conc. of } \\
\text { oxidized spermine } \\
\text { (mM) }\end{array}$} & \multirow{2}{*}{$\begin{array}{l}\text { Oxidized spermine } \\
\text { remaining in the } \\
\text { spermatozoa } \\
\left(\mathrm{nmol} / 10^{8} \text { cells) }\right.\end{array}$} & \multicolumn{2}{|c|}{ Formation (pmol $/ 10^{8}$ cells) of: } \\
\hline & & ${ }^{14} \mathrm{CO}_{2}(\%)$ & {$\left[{ }^{14} \mathrm{C}\right]$ lactate $(\%)$} \\
\hline $\mathbf{0}$ & 0 & $2800(100)$ & $8060(100)$ \\
\hline 0.05 & 4.0 & $2260(81)$ & $6110(76)$ \\
\hline $0 \cdot 1$ & $9 \cdot 7$ & $1000(44)$ & $3230(40)$ \\
\hline 0.2 & $20 \cdot 9$ & $200(7)$ & $830(10)$ \\
\hline 0.5 & $48 \cdot 8$ & $32(1)$ & $290(3 \cdot 5)$ \\
\hline 1.0 & $84 \cdot 6$ & $12(0 \cdot 4)$ & $62(0 \cdot 8)$ \\
\hline $0.5+$ & 41.9 & $78(3)$ & $400(5)$ \\
\hline $5 \mathrm{~mm}$ spermine & & & \\
\hline
\end{tabular}

Table 5. The effect of oxidized spermine on the production of ${ }^{14} \mathrm{CO}_{2}$ and $\left[{ }^{14} \mathrm{C}\right]$ lactate by intact human spermatozoa and cell-free sperm extracts

\begin{tabular}{|c|c|c|c|c|}
\hline \multirow[b]{2}{*}{ Additions } & \multicolumn{2}{|c|}{${ }^{14} \mathrm{CO}_{2}$} & \multicolumn{2}{|c|}{$\left[{ }^{14} \mathrm{C}\right]$ Lactate } \\
\hline & $\begin{array}{c}\text { pmol } / \\
10^{8} \text { cells }\end{array}$ & $\begin{array}{l}\% \text { of } \\
\text { control }\end{array}$ & $\begin{array}{c}\text { pmol } / \\
10^{8} \text { cells }\end{array}$ & $\begin{array}{l}\% \text { of } \\
\text { control }\end{array}$ \\
\hline \multicolumn{5}{|l|}{ (1) Intact cells } \\
\hline None & 820 & 100 & 1,890 & 100 \\
\hline $\begin{array}{l}0.5 \text { mM-oxidized } \\
\text { spermine }\end{array}$ & 170 & 21 & 810 & 43 \\
\hline \multicolumn{5}{|l|}{ Cell-free extracts } \\
\hline None & - & - & 11,090 & 100 \\
\hline $\begin{array}{l}0.5 \text { mM-oxidized } \\
\text { spermine }\end{array}$ & - & - & 10,740 & 97 \\
\hline \multicolumn{5}{|l|}{ (2) Intact cells } \\
\hline None & 570 & 100 & 1,580 & 100 \\
\hline $\begin{array}{l}1 \text { mM-oxidized } \\
\text { spermine }\end{array}$ & 78 & 14 & 320 & 20 \\
\hline \multicolumn{5}{|l|}{ Cell-free extracts } \\
\hline None & - & - & 15,110 & 100 \\
\hline $\begin{array}{l}1 \text { mM-oxidized } \\
\text { spermine }\end{array}$ & - & - & 12,740 & 84 \\
\hline
\end{tabular}

Table 6. Effect of various aldehydes on sperm fructolysis (no. of experiments in parentheses)

\begin{tabular}{|c|c|c|}
\hline \multirow{2}{*}{$\begin{array}{l}\text { Aldehyde } \\
\text { (1 mM) }\end{array}$} & \multicolumn{2}{|c|}{ Formation ( $\%$ of control \pm S.D.) of: } \\
\hline & ${ }^{14} \mathrm{CO}_{2}$ & {$\left[{ }^{14} \mathrm{C}\right]$ lactate } \\
\hline Oxidized spermine & $2 \cdot 3 \pm 2 \cdot 6^{* * *}(5)$ & $9 \cdot 5 \pm 6 \cdot 0^{* * *}(4)$ \\
\hline$n$-Hexanal & $4.6 \pm 2.7^{* * *}(3)$ & $28 \cdot 0 \pm 20 \cdot 0^{*}(3)$ \\
\hline Salicyl aldehyde & $42.8 \pm 31.4^{* *}(5)$ & $75 \cdot 5 \pm 16 \cdot 0^{*}(4)$ \\
\hline Glycol aldehyde & $58 \cdot 1 \pm 23 \cdot 5(3)$ & $48 \cdot 8,100 \cdot 2(2)$ \\
\hline Formaldehyde & $61.0 \pm 13 \cdot 0^{*}(3)$ & $56 \cdot 9,104 \cdot 3(2)$ \\
\hline Anisaldehyde & $69.8 \pm 2.0^{* * *}(3)$ & $58.9,97.4(2)$ \\
\hline Acetaldehyde & $96.7 \pm 4.5(3)$ & $70 \cdot 0,97 \cdot 1(2)$ \\
\hline Benzaldehyde & $100.7 \pm 5.0(3)$ & $88.5,99 \cdot 5(2)$ \\
\hline
\end{tabular}

Significantly different from control value $(100 \%) ; * P<0.05 ; * * P<0.01$; ${ }^{* * *} P<0.001$ (Student's $t$ test). 


\section{Discussion}

Human semen normally contains high concentrations of spermine (Mann, 1964) and also high but variable activities of diamine oxidase (Jänne, Hölttä, Haaranen \& Elfving, 1973). The latter enzyme appears to be capable of oxidizing polyamines such as spermine and spermidine to products resembling labile iminoaldehydes (Hölttä, Pulkkinen, Elfving \& Jänne, 1975). Although the physiological or pathophysiological significance of the oxidation products of polyamines in human semen remains to be established, some recent observations indicate that high diamine oxidase activity in seminal plasma may be associated with decreased motility of sperm cells (Hölttä et al., 1975; Crabbe, 1976). The assay of diamine oxidase activity has been suggested as the basis of a routine assessment of human semen samples for estimation of male infertility (Crabbe, 1977).

The exact mechanism by which oxidized polyamines exert their toxic effect on mammalian spermatozoa is not known. It is, however, obvious from the present results that oxidized spermine does not affect any specific reactions of glycolysis but appears to bind to the sperm membrane and depress the uptake of substrates such as sugars and lactic acid. It is also evident that the iminoaldehydes inhibit fructose uptake by a mechanism which is not a simple competition of the aldehyde with fructose for a common transport system. It is possible, even likely, that the amino groups and the terminal aldehyde groups of oxidized spermine are involved in the interaction of the compound with mammalian spermatozoa. This suggestion is supported by the finding that simple aldehydic compounds, except perhaps $n$-hexanal, were virtually without effect on fructolysis. $n$-Hexanal does, however, resemble oxidized polyamines in its molecular size. The fact that oxidized polyamines are effective at very low concentrations and that they appear to interact with structures involved in the transport of important substrates of sperm energy metabolism, may make them useful as tools, not only as specific spermicidal compounds but also for studies to elucidate the structure and function of sperm cell membranes.

This investigation received financial support from the World Health Organization and from the Ford Foundation.

\section{References}

CrabBe, M.J.C. (1976) Enzyme assay for sperm motility. Lancet ii, 1295.

CRABbe, M.J.C. (1977) The development of a qualitative assay for male infertility from a study of enzymes in human semen. J. Reprod. Fert. 51, 73-76.

Eliasson, R. (1971) Oxygen consumption of human spermatozoa in seminal plasma and a Ringer solution. J. Reprod. Fert. 27, 385-389.

Hölttä, E., Pulkkinen, P., Elfving, K. \& JänNe, J. (1975) Oxidation of polyamines by diamine oxidase from human seminal plasma. Biochem. J. 145, 373378.

Hoskins, D.D. \& Patterson, D.L. (1968) Metabolism of Rhesus monkey spermatozoa. J. Reprod. Fert. 16, 183-195.

Jänne, J., Hölttä, E., HaAranen, P. \& Elfving, K. (1973) Polyamines and polyamine-metabolizing enzyme activities in human semen. Clin. chim. Acta 48, 393-401.

MaNn, T. (1964) The Biochemistry of Semen and of the
Male Reproductive Tract, pp. 194-200. Methuen, London.

Murdoch, R.N. \& White, I.G. (1968) Studies of the metabolism of human spermatozoa. J. Reprod. Fert. 16, 351-361.

Pulkkinen, P., Kanerva, S., Elfving, K. \& Jänne, J. (1975a) Association of spermine and diamine oxidase activity with human spermatozoa. J. Reprod. Fert. 43, 49-55.

Pulkkinen, P., Sinervirta, R. \& JänNe, J. (1975b) Modification of the metabolism of rat epididymal spermatozoa by spermine. Biochem. biophys. Res. Commun. 67, 714-722.

Tabor, C.W. \& Rosenthal, S.M. (1956) Pharmacology of spermine and spermidine. Some effects on animals and bacteria. J. Pharmac. exp. Ther. 116, 139-155.

YAMADA, H. \& YAsunotu, K.T. (1962) Monoamine oxidase. I. Purification, crystallisation and properties of plasma monoamine oxidase. J. biol. Chem. 237, 1511-1516. 